\title{
Taku Glacier (Alaska, U.S.A.) on the move again: active deformation of proglacial sediments
}

\author{
Roman J. MOTYKA, Keith A. ECHELMEYER \\ Geophysical Institute, University of Alaska Fairbanks, 903 Koyukuk Drive, P.O. Box 757320, Fairbanks, Alaska 99775-7320, U.S.A. \\ E-mail:jfrjm@uas.alaska.edu
}

\begin{abstract}
Taku Glacier is one of the few glaciers in Alaska, U.S.A., that has advanced over the last century: $7 \mathrm{~km}$ since 1890. This advance slowed substantially during the past decade, but in summer 2001 the glacier terminus began to readvance at a rate of $30 \mathrm{~cm} \mathrm{~d}^{-1}$. The advance produced dramatic proglacial sediment deformation up to $200 \mathrm{~m}$ in front of the terminus. Two to three large bulges and several secondary bulges developed in the proglacial sediments as a result of glacial compression along a $1 \mathrm{~km}$ wide portion of the terminus. The bulge nearest the terminus was $10 \mathrm{~m}$ high and $65 \mathrm{~m}$ wide. The middle bulge $(7 \mathrm{~m}$ high) advanced at $15 \mathrm{~cm} \mathrm{~d}^{-1}$ and the distal bulge $\left(3 \mathrm{~m}\right.$ high and $50 \mathrm{~m}$ wide) at $9 \mathrm{~cm} \mathrm{~d}^{-1}$. Crenulations and prominent fractures developed in the overlying vegetation layer. The frontal lobes of the bulges were steep and overlaid a shear zone, where sediments were being thrust up and over the ground surface. Ice-proximal push moraines, 1-10 m high, formed along much of the $9 \mathrm{~km}$ wide terminus, although deformation was minimal at some locations.
\end{abstract}

\section{INTRODUGTION}

Taku Glacier, located nearJuneau, Alaska, U.S.A., is one of the few glaciers in North America that has been advancing over the last century. It has advanced $7 \mathrm{~km}$ since 1890 (Fig. 1; Motyka and Post, 1995; Post and Motyka, 1995). Initially a tidewater glacier, a proglacial shoal developed by 1950 and subaerial push moraines ${ }^{*}$ developed along the terminus in subsequent decades, as the terminus advanced into and onto shoal sediments (Motyka and others, 1992; Post and Motyka, 1995). Although the advance slowed substantially during the last decade, the terminus, on average, continues to advance in response to thickening up-glacier. In summer 2001, a section of the terminus began a strong readvance. Ice-proximal push moraines were generated along broad portions of the terminus, but there was also dramatic deformation of raised proglacial sediments for as much $200 \mathrm{~m}$ beyond the advancing ice front. Here we report on reconnaissance investigations of this dynamic behavior, including measurements of the glacier's thickening and advance, and the ensuing proglacial sediment deformation.

\section{Active glaciotectonism}

Ice-terminal glaciotectonic landforms have long been a subject of interest and have received significant attention because of their ubiquitous occurrence in glaciated terrain and because of their implications for the dynamics at advancing

\footnotetext{
* We use Bennett's (2001) definition of "push moraine" as the product of construction by the deformation of ice, sediment and/or rock to produce a ridge, or ridges, transverse or oblique to the direction of ice flow in front of, at, or beneath an ice margin.
}

termini (see Croot (1988a), Aber and others (1989) and Bennett (2001) for reviews). Structures thought to be of glaciotectonic origin abound along the perimeters of Pleistocene continental glaciations (Van der Meer, 1987), and have been reported for Little Ice Age (LIA) and more recent advances (e.g. Humlum, 1985; Croot, 1987; Eybergen, 1987; Hart, 1995). Despite the widespread occurrence of these structures and landforms in glaciated regions, there have been few direct measurements of their formation at advancing temperateglacier ice fronts, principally because very few of these glaciers have been advancing during the last several decades. Several studies have documented development of proglacial thrust slabs in permafrosted forelands of advancing, and in some cases surging, polar glaciers, mainly in Svalbard, Norway (e.g. Hagen, 1987; Croot, 1988b; Etzelmüller and others, 1996; Hart and Watts, 1997; Boulton and others, 1999), and also on Axel Heiberg Island, Canada (Kälin, 1971).

The proglacial deformation that accompanies surgingglacier advances in permafrosted terrain may not accurately represent the much broader realm of slowly advancing (a few to tens of meters per year), non-surging temperate glaciers that likely characterized lower-latitude Pleistocene and lateHolocene glacial expansions. Previous studies on pushmoraine development on advancing temperate glaciers include Höfðabrekkujökull, Iceland (Humlum, 1985; Krüger, 1985) and Turtmanngletscher, Switzerland (Eybergen, 1987). The current advance of Taku Glacier now provides another opportunity to study the effects of slow terminus advance and the proglacial sediment deformation that accompanies it.

\section{BAGKGROUND ON TAKU GLAGIER AND ITS ADVANGE}

Taku Glacier $\left(700 \mathrm{~km}^{2}\right)$ is the primary outlet glacier draining the $1820 \mathrm{~km}^{2}$ Juneau Icefield (Fig. 1). It contains the deepest 

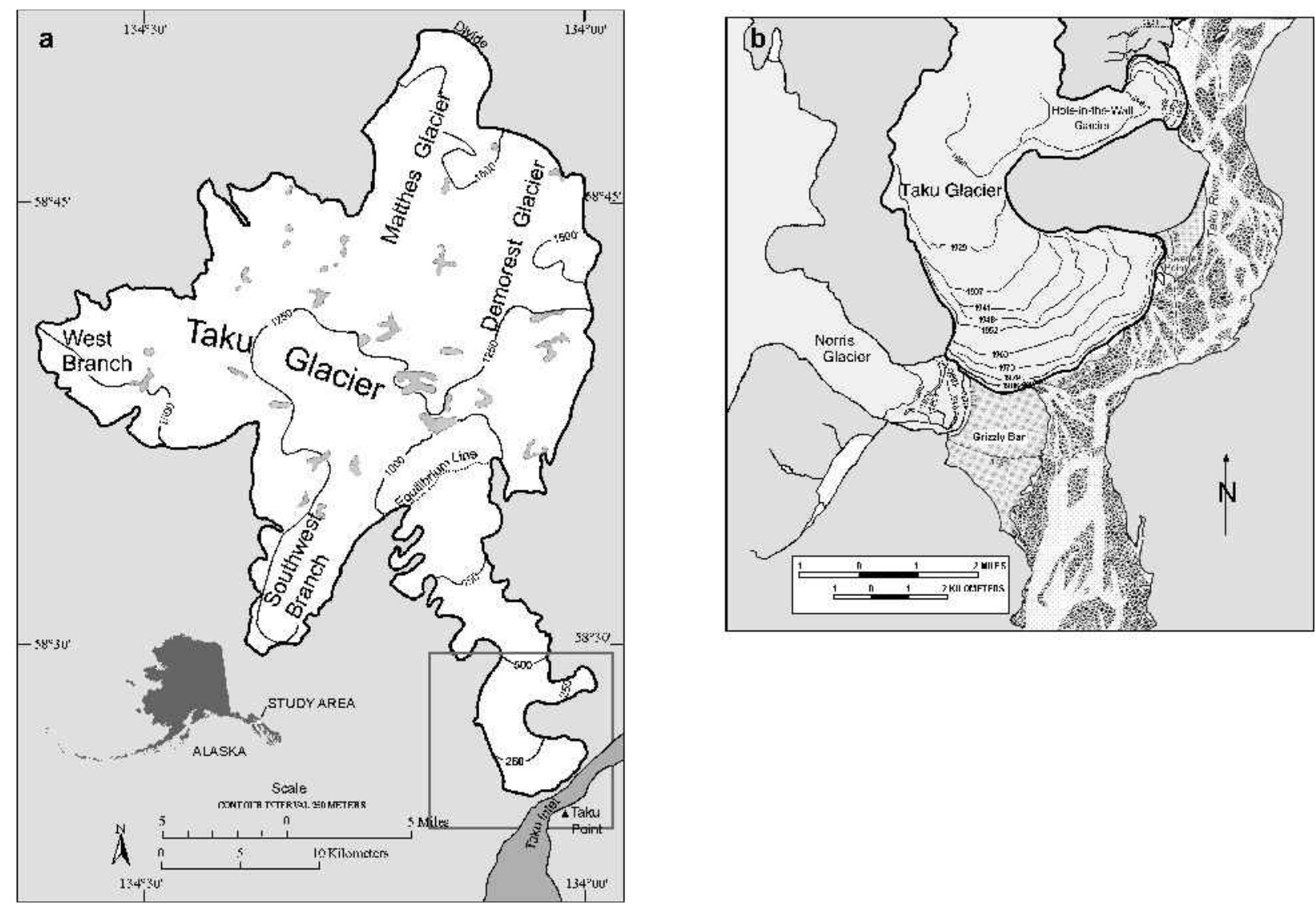

Fig. 1. (a) Taku Glacier, covering approximately $700 \mathrm{~km}^{2}$ in the Coast Mountains of southeast Alaska. Terminus in box expanded in (b). The glacier has advanced $7 \mathrm{~km}$ over soft sediments since 1890.

ice $(1500 \mathrm{~m}$ ) yet measured in Alaska, and the bed is below sea level for about 40 of its $60 \mathrm{~km}$ length (Nolan and others, 1995). The glacier is located in a maritime-climate zone, with large amounts of winter snowfall and high rates of summer ablation (typically $10-12 \mathrm{~m} \mathrm{a}^{-1}$ near the terminus; Pelto and Miller, 1990; R.J. Motyka, unpublished data). Surface velocity in 1990, $2 \mathrm{~km}$ up-glacier from the terminus, was $150 \mathrm{ma}^{-1}$ (R. J. Motyka, unpublished data). The terminus forms a piedmont lobe over its outwash plain with a terminus width of about $9 \mathrm{~km}$.

The glacier repeatedly blocked Taku River during the late Holocene, most recently during the culmination of the LIA in about AD 1750 (Motyka and Begét, 1996). A rapid calving retreat began shortly thereafter. The glacier ended in tidewater during the early 20th century, and actively calved into a fjord >100 m deep (Motyka and Post, 1995). By 1890 it began to readvance, filling in the fjord with sediment and glacier ice. This advance continued for a total of $7 \mathrm{~km}$ through 1990, during which time the glacier actively excavated and entrenched itself into subglacial sediments that filled the distal part of the fjord (Figs 1 and 2; Motyka and Post, 1995; Nolan and others, 1995). Excavated sediments were deposited as glacier outwash and, together with sediments from Taku River, helped fill upper Taku Inlet (Motyka and Post, 1995). The deposition and deformation of proglacial sediments was eventually sufficient to raise the level of the proglacial shoal above sea level by 1950, forming an apron 5-10 $\mathrm{m}$ above sea level and several hundred meters wide. Ice-proximal push moraines, a few meters wide, developed along most of the face. However, a much larger pushmoraine complex whose distal edge lay 100-200 m from the face, developed along the central portion of the terminus by the mid 1960s. This broad area of deformation has remained in approximately the same relative location with respect to the face, as the glacier continued to advance in subsequent years (Motyka and others, 1992; Post and Motyka, 1995).

The advance of Taku Glacier is related to the advance phase of the "tidewater-glacier cycle" (Post, 1975; Post and Motyka, 1995). The 19th century calving retreat resulted in a large accumulation-area ratio (AAR; $\sim 0.90)$ during most of the 20th century. The large AAR, and reduced calving due to fjord infilling by glacial and fluvial sediments, resulted in a positive net balance for a number of decades (Pelto and Miller, 1990). This has driven the current advance (Post and Motyka, 1995).

Airborne altimetry (Echelmeyer and others, 1996) of Taku Glacier and about 100 other glaciers around Alaska and northwest Canada indicate that Taku Glacier is one of

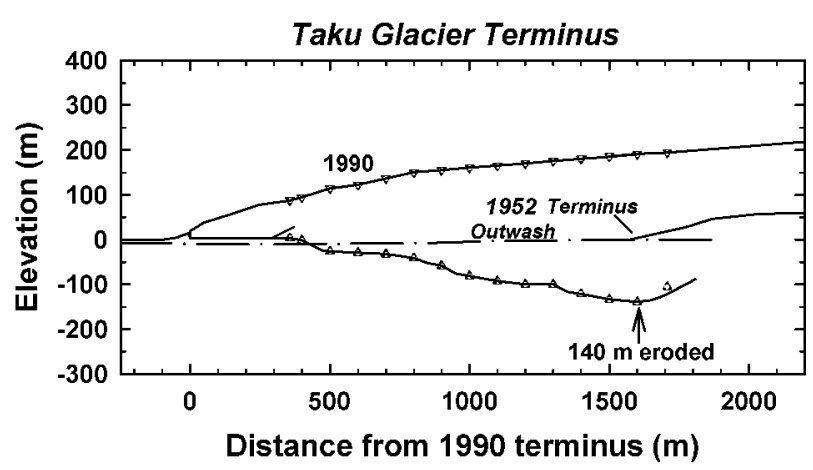

Fig. 2. Ice thickness and bed elevation of lower Taku Glacier in 1990. Glacier excavated $140 \mathrm{~m}$ of sediments from 1952-90. 

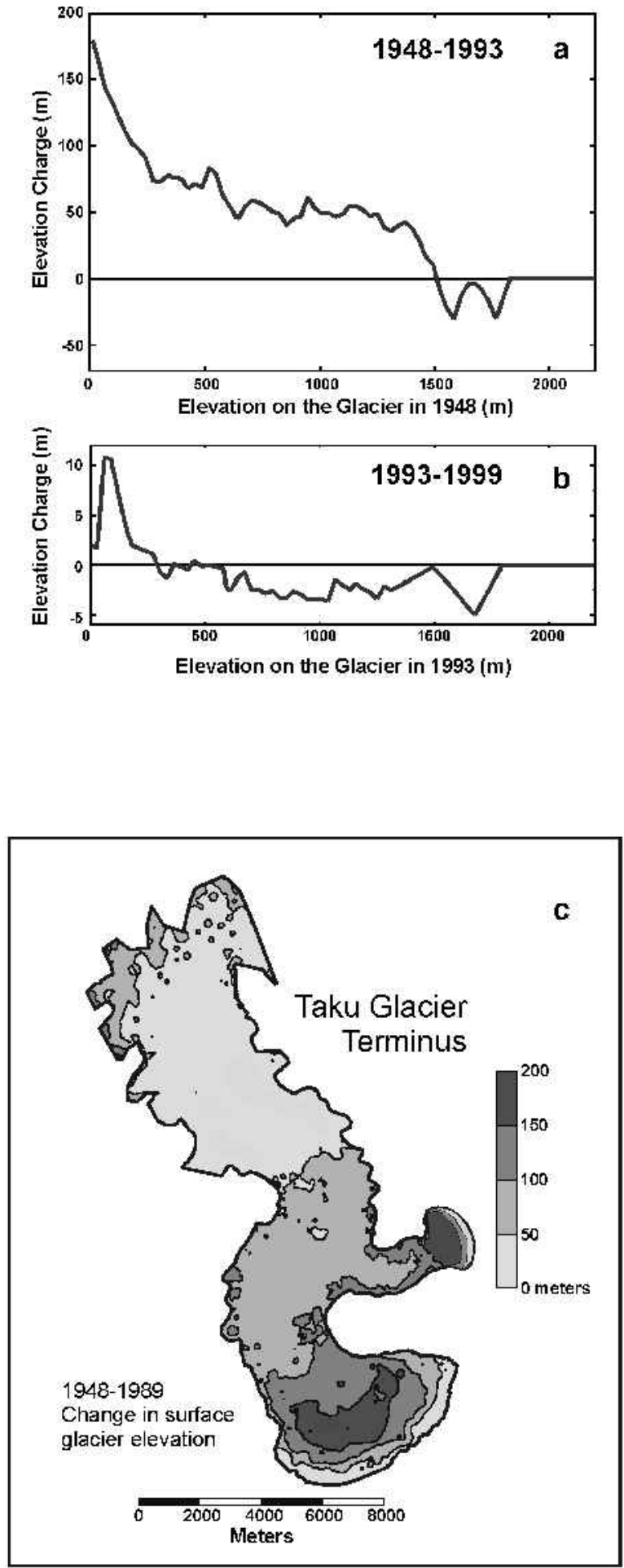

Fig. 3. Surface-elevation changes of the glacier from longitudinal airborne profiling (a) for 1948-93, (b) for 1993-99 and (c) 1948-89 isopachs for the terminus region from aerial photography.

the few glaciers that has thickened over the last half century - almost all others have thinned dramatically (Arendt and others, 2002). From 1948-93 the glacier-wide average thickening on Taku Glacier was $31 \mathrm{~m}$, or $0.7 \mathrm{~m} \mathrm{a}^{-1}$. Over the same period the terminus region thickened by $160 \mathrm{~m}$, or $3 \mathrm{~m} \mathrm{a}^{-1}$ (Fig. 3). An overall advance of $\sim 1.5-2 \mathrm{~km}$ accompanied this thickening, at an average rate of $40 \mathrm{~m} \mathrm{a}^{-1}$ (Figs 1 and 2). The "Hole-in-the-Wall" glacier also advanced as thickening ice increased flow into this distributary.

From 1993-99 the terminus region continued to thicken, but at a reduced rate (Fig. $3 \mathrm{~b}$ ). Even though much of the glacier thinned over this period, the thickening over the last $7 \mathrm{~km}$ of the terminus region caused an overall advance. The rate of advance was $8 \mathrm{~m} \mathrm{a}^{-1}$ in the mid 1990s at sites A and B in Figure $4 \mathrm{a}$, while other parts showed either no terminus change (site C, Fig. 4a) or even slight retreat (site D). The terminus generally advanced faster from 1999 to spring 2001 than it did in the mid 1990s (Fig. 4a).

Starting in spring 2001, part of the terminus (Fig. 4b) began to advance faster. We made reconnaissance measurements of the advancing terminus and the proglacial sediment deformation using differential and geodetic GPS methods in early June, September and November 2001, and in late June and late August 2002. We also dug shallow trenches into several distal bulges to expose sediment structure and took advantage of an outwash-stream cutbank through one of the bulges. Terminus advance averaged $20-37 \mathrm{~cm} \mathrm{~d}^{-1}$ near site $\mathrm{B}$ from June-September 2001, but there was no net advance from September-November 2001. The glacier resumed its advance in spring 2002 and averaged $20-30 \mathrm{~cm} \mathrm{~d}^{-1}$ from June-August 2002. As in previous advances, not all parts of the terminus advanced during summer 2001 and some thinning and retreat even occurred at site D. However, most of the terminus advanced during summer 2002.

\section{PROGLAGIAL SEDIMENT DEFORMATION}

As the glacier advanced over and into proglacial sediments, several different effects were evident along the portion of the terminus investigated (Fig. 4b), including the toppling of trees and bushes, bulldozing of surface sediments into frontal push moraines and the formation of several distal bulges. These occurred along a $1 \mathrm{~km}$ wide section of the terminus where sediments were raised 5-15 $\mathrm{m}$ higher than adjacent outwash plains, but not elsewhere.

\section{Ice-proximal features}

In the summers of 2001 and 2002, advancing ice formed iceproximal push moraines along much of the terminus. These features ranged from $1-10 \mathrm{~m}$, but were generally $3-5 \mathrm{~m}$ high with widths typically 2-3 times the height (Fig. 5). Advancing ice bulldozed and overrode sediments and vegetation. Glacier ice was directly in contact with most of these moraines early in the ablation season, but melting exposed the stoss side of some moraines by late summer. Stoss slopes were typically $15-20^{\circ}$, but in some cases were as steep as $50^{\circ}$, similar to the soles of adjacent ice. Down-glacier moraine slopes were $40-45^{\circ}$.

Trenches show that these moraines were composed of a core of deformed glacier-outwash sediments covered by flow, melt-out, and subglacial tills. The composite till had little or no structure and was composed of boulders and cobbles in a matrix of sand, silt and mud. Fresh willow and spruce fragments incorporated in the till show that the glacier was actively eroding terrain that had been overrun recently. Deposition of till and bulldozing caused the down-glacier side of the moraine to reach the angle of repose with debris spalling off and burying vegetation forward of the moraine.

The deformation of surficial outwash deposits within these ice-proximal push moraines was relatively restricted, 1-2 m deep and somewhat wider. A stake set several meters in front of one of the advancing push moraines in 2001 remained undisturbed, despite subsequent moraine encroachment to within $2 \mathrm{~m}$ of the stake in 2002. Deformation was strongest 

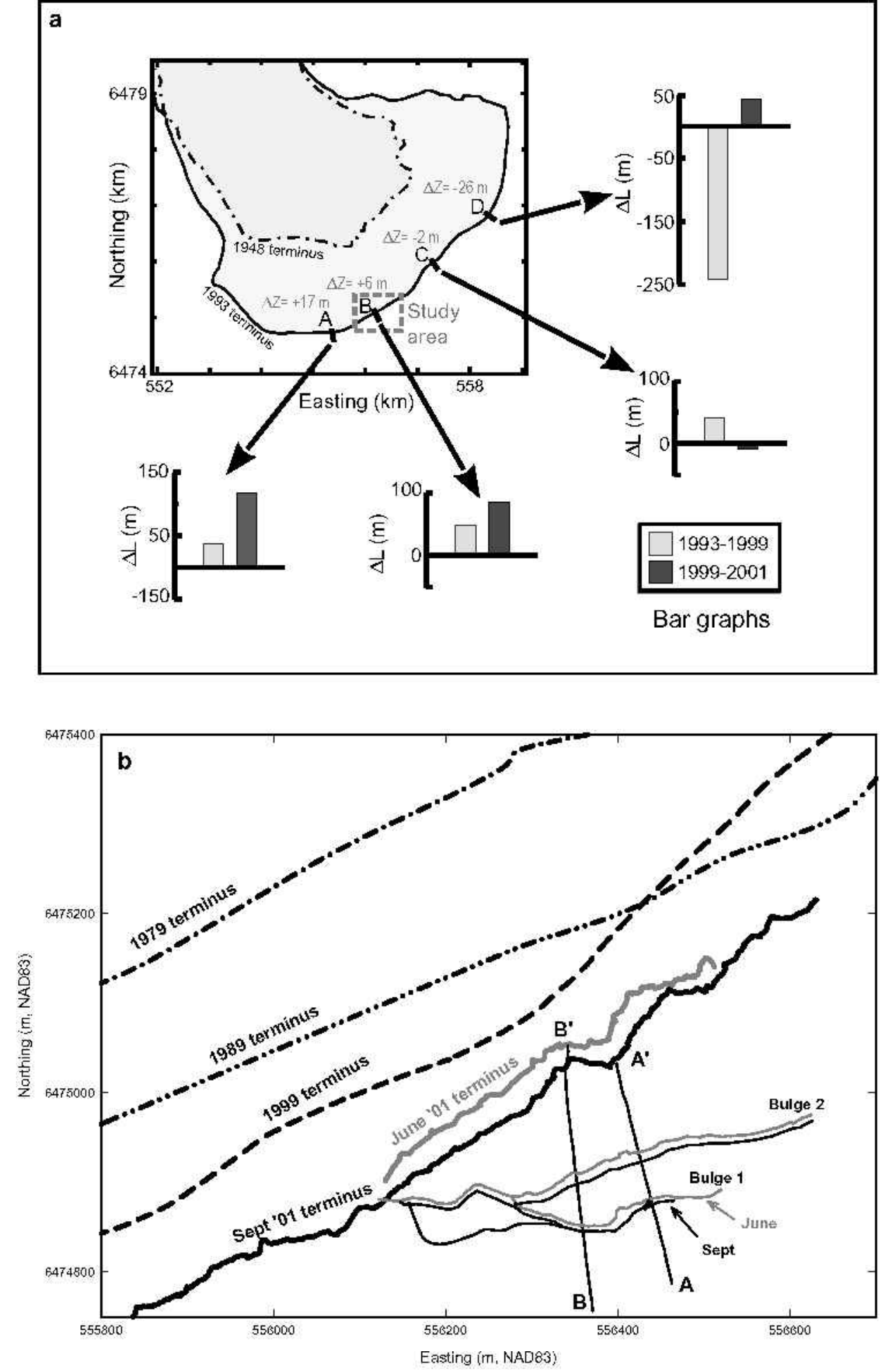

Fig. 4. (a) Activity at four points along the current terminus. $\Delta L$ is the lateral change in the terminus position and $\Delta Z$ is the change in the ice-surface elevation. (b) Detail of the study site outlined by dashed box in Figure 4a. Elevations have been measured along lines $A$ and $B$ ( see Fig. 7).

directly forward of the advancing ice, where surficial layers of sediments and the overlying organic mat were bulldozed upward and overturned. In contrast, deeper sediments, as well as sediments forward of the push moraines, were generally undeformed. Sediments underlying the ice front commonly dipped up-glacier, in places as much as $10-15^{\circ}$.

\section{Deformational bulges}

In addition to the ice-proximal features, there was dramatic deformation of proglacial sediments up to $200 \mathrm{~m}$ from the terminus (Figs 6 and 7). The surface and underlying sediments in this region (consisting of outwash sand, silt and a few larger clasts) formerly sloped gently away from the ice front, as evidenced by aircraft tracks present on the now-deformed surface (Fig. 6). Two to three several-meter-high prominent bulges and several secondary bulges subsequently formed in these proglacial sediments. The deformation caused folding, buckling and tearing of the overlying mat of vegetation (Fig. 6). Bulge 3 (closest to the ice, where there were three distinct 


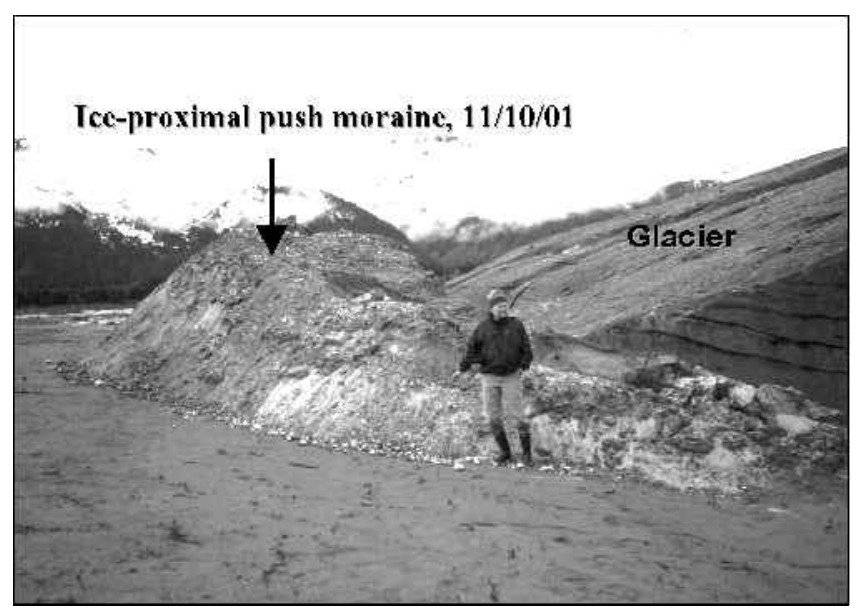

Fig. 5. Push moraine generated by 2001 advance. Terminus is visible to right. Bulldozed surface sediments are mantled by till. Back of moraine is partially covered by slivers of ice.

bulges) was $10 \mathrm{~m}$ high and $65 \mathrm{~m}$ wide, while bulge 2 was $7 \mathrm{~m}$ high and $75 \mathrm{~m}$ wide and the distal bulge (1) was $3 \mathrm{~m}$ high and $50 \mathrm{~m}$ wide (Fig. 7). As the ice advanced, bulge 2 propagated forward at $15 \mathrm{~cm} \mathrm{~d}^{-1}$ and bulge 1 at $9 \mathrm{~cm} \mathrm{~d}^{-1}$, rates that are roughly half the rate of glacier advance. There was no change in the bulges after September 2001, but portions were reactivated during summer 2002.

At some locations, several smaller-scale bulges, $0.5-1 \mathrm{~m}$ high, developed on the larger bulges. Small-scale folding in the overlying vegetation layer was also observed on top of the sediment bulges at several locations. This vegetation layer was often decoupled from the underlying soil, with crenulations and folds of amplitude $0.1-0.3 \mathrm{~m}$ and wavelength $0.1-0.6 \mathrm{~m}$ (Fig. 6).

Surface profiles, trenching and exposures in stream cutbanks revealed a distinctive morphology and similar deformational features in all these bulges, regardless of size. The underlying sediments consist primarily of poorly consolidated layers of glacier outwash (silt, sand and gravel), with occasional interbedded thin layers of mud $(<1 \mathrm{~cm})$. The frontal lobes of the bulges tend to be abrupt and relatively steep $\left(30-45^{\circ}\right)$ (Figs 6 and 7), while the ground surface between snouts is relatively even and in some cases dips gently upglacier. The underlying outwash bedding follows a similar pattern: sediment beds distal to the snout appear undisturbed and exhibit dips similar to the overlying surface, whereas sediments near the snout are deformed and dip steeply downslope (Fig. 8). The snouts of the bulges have clearly been thrust over the downslope ground surface as evidenced by buried organic mats, which in some cases were quite fresh. These buried organic layers helped define prominent shear zones that dipped up-glacier at angles up to $30-40^{\circ}$ near the toe of the bulges (Fig. 8); sediment layers above these were commonly tightly folded, contorted and in some cases overturned (Fig. 8). The dip of the thrust plane rapidly diminished and the zone became less distinct within a few meters of the toe. Sediments directly underlying and in front of the shear zone dipped moderately up-glacier, then underwent a transition to sub-horizontal with both depth and distance from the toe.

\section{DISGUSSION}

Features associated with advancing glaciers were evident along the terminus of Taku Glacier and its distributary,
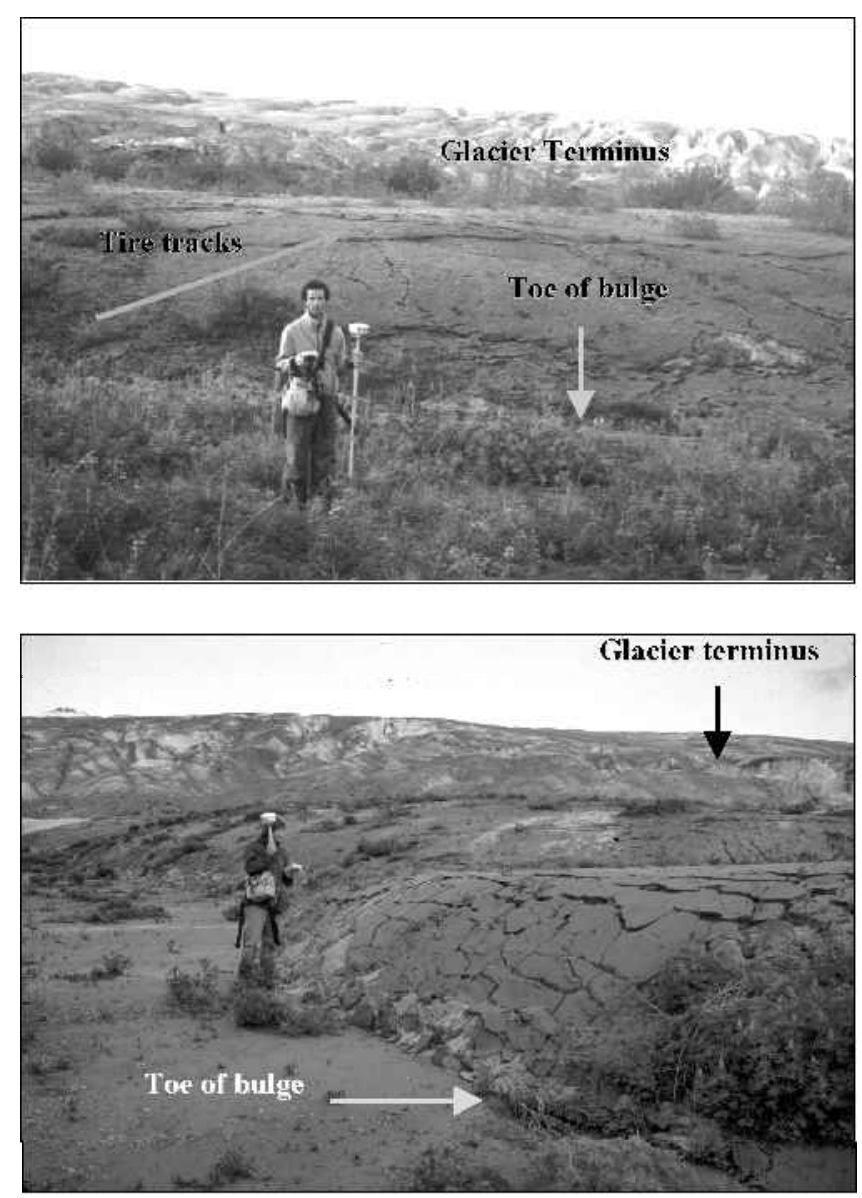

Fig. 6. Distal bulges in proglacial sediments produced in 2001. Propagation of sediment deformation by advancing ice, creating crenulations, folds and tears in overlying organic mat. These distal bulges lie about $200 \mathrm{~m}$ from the terminus.

Hole-in-the-Wall Glacier. These include splaying crevasses on a steep snout, push moraines, ice-bulldozed vegetation, freeze-on basal layers of ice that have incorporated this vegetation, fluted sediments and large bulges in proglacial sediments, as described above. Regions of relatively undisturbed sediments also occurred along the terminus, indicating some critical combination of factors necessary for proglacial sediment deformation. Speed of advance is probably important. The relative height of proglacial sediments, which can present a "restraining wall" to glacier advance, has been suggested as a factor (Humlum, 1985). Our observations of sediment deformation were made where there is a large area (several hundred $\mathrm{m}^{2}$ ) of super-elevated proglacial sediments. In the following sections, we discuss continued glacier advance, compare proglacial sediment deformation at Taku Glacier with push moraines found elsewhere and then present a speculative model on how the long-wavelength bulges may have formed.

\section{Glacier advance}

Taku Glacier witnessed a substantial reduction in the rate of terminus advance in the 1990s despite continued thickening of the lower glacier. Several factors may be contributing to the slowdown: first, by the late 20 th century the terminus had broadened into a piedmont lobe thus dispersing the increased ice flux over a broader region (Motyka and Post, 1995); second, continued excavation of soft subglacial sediments likely accommodated some of the increased ice flux in the terminus region (Nolan and others, 1995); and third, 


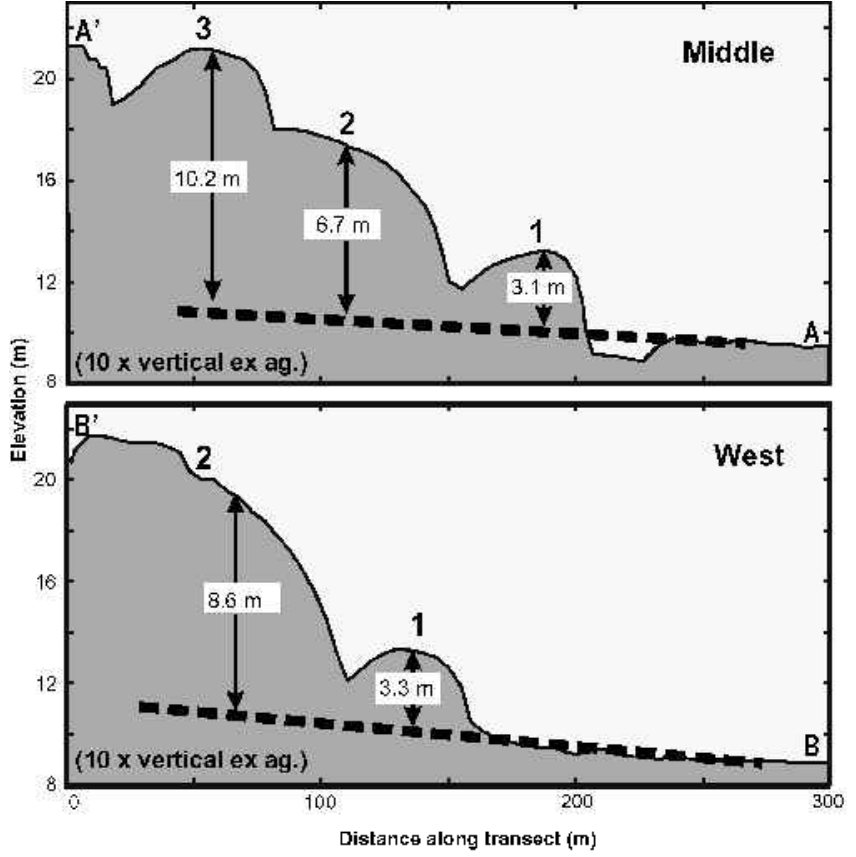

Fig. 7. Cross-sectional view along lines A and B in 2001 (see Fig. $4 b)$. Bulges are numbered.

as the glacier thickened, a distributary glacier (Hole-in-theWall Glacier) advanced, capturing more of the increased ice flux (Fig. 1b). Another influence may be increased ablation at the glacier front caused by changing climate; the average summer temperature in Juneau has risen about $1 \mathrm{~K}$ since 1977 (Motyka and others, 2002).

We do not know how long the advance will continue, nor can we be certain that proglacial sediment deformation will continue in the same locations as during 2001 and 2002. It is likely that the terminus ice will continue to thicken and advance, at least for a few years. This is because the ice just upstream has thickened during 1994-2000 and 2000-01, as determined by airborne altimetry (Arendt and others, 2002; Fig. 4). Our study area (site B, Fig. 4) will most likely continue to be affected by the advance because it forms a superelevated mound of sediment in comparison to much of the terminus region.

In the long term (several years hence), continuing advance of Taku Glacier of course depends on its mass balance and changes in AAR. The glacier's equilibrium-line altitude is near a critical elevation where the glacier begins to flatten, small rises could thus lead to large changes in AAR (Fig. 1).

\section{Push moraines: comparison to observations elsewhere}

Taku Glacier is a temperate, non-surging glacier. Permafrost does not occur in this maritime zone. Thus, the formation of proglacial deformational features, such as those at Taku Glacier, provide evidence that permafrost conditions are not necessary to produce large-scale push moraines (see also Humlum, 1985; Bennett, 2001). Taku Glacier has similarities to Höfðebrekkujökull: both glaciers occur in maritime zones, have broad piedmont lobes, are of similar size and advanced at similar rates onto broad outwash aprons. The ice-proximal push moraines at Taku are geomorphologically similar to at least one type of push moraine reported by Humlum (1985)

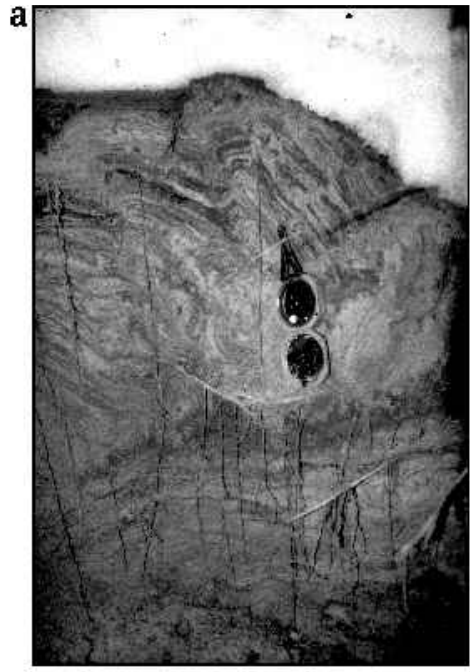

b

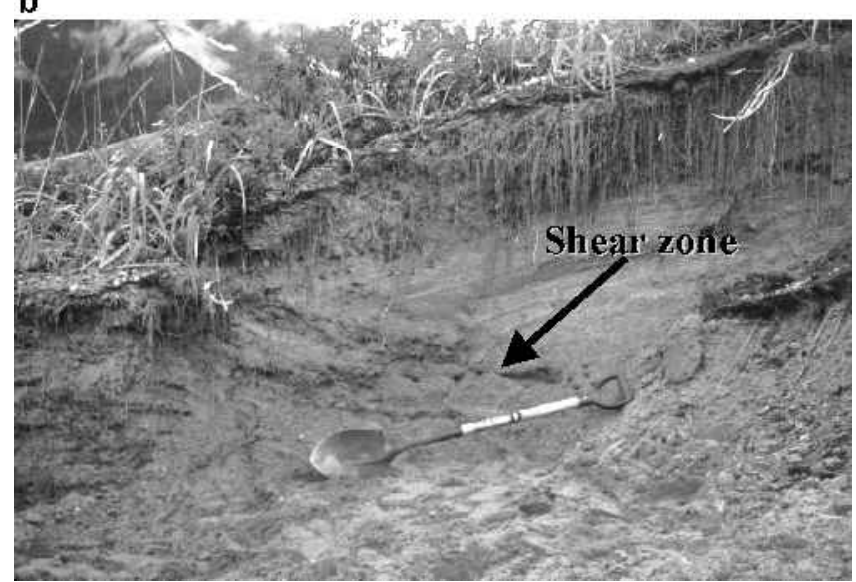

Fig. 8. Structure of sediments at the fronts of bulges exposed by excavation and by stream cuts. (a) Sediment deformation exposed in trench at toe of a distal bulge. Shear zone underlies compass. (b) Front of bulge exposed by stream cut. Arrow points to shear zone.

and Krüger (1985) at Höfðebrekkujökull. These moraines appear to have been generated as ice-pushed thrust slabs of proglacial sediments subsequently mantled by till. However, we have not observed the multiple stacking of thrust slabs as seen at Höfðebrekkujökull, which can produce imbricate push moraines 10-20 m wide. One factor may be debris cover. Höfðebrekkujökull, which covers an active volcano, has a terminus that is laden with a thick layer of volcanic ash and larger debris. This debris quickly mantles the push moraines. In contrast, Taku Glacier has a relatively clean terminus and buildup of till is slow. Another factor may be the manner of glacier advance. At Taku, terminus ice often pushes steeply up the backside of the ice-proximal push moraines (Fig. 5) rather than pushing horizontally and generating additional thrust slabs in proglacial sediments, as suggested by observations at Höfðebrekkujökull.

The long-wavelength deformational bulges documented at Taku Glacier do not have an analogue at Höfðebrekkujökull, but there are some similarities to proglacial deformational features observed at Turtmanngletscher (Eybergen, 1987). We note that Taku Glacier is two orders of magnitude larger than Turtmanngletscher in both area and length. At Turtmanngletscher, a sustained glacier advance caused deformation of a wedge of glaciofluvial sediment overlying 


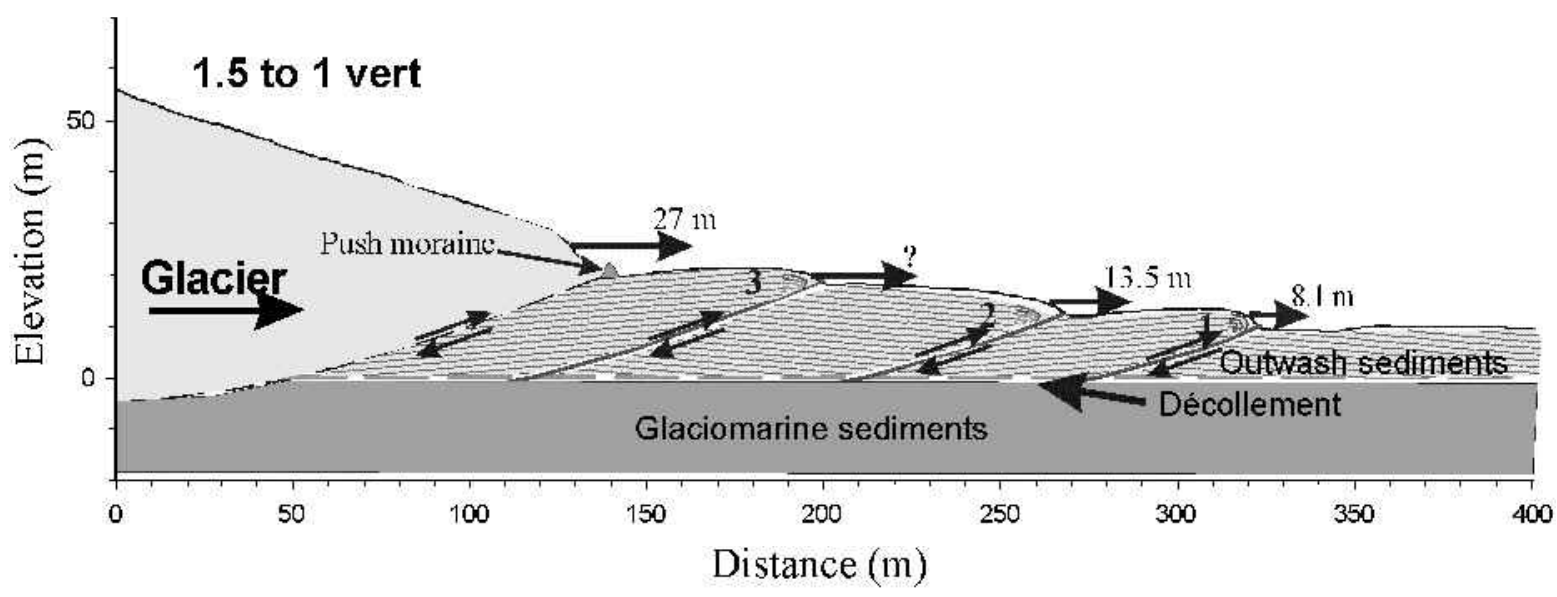

Fig. 9. Model of proglacial sediment deformation at Taku Glacier. Advancing ice is applying pressure to proglacial sediments to depths of at least 20-30 m below the surface. At the terminus, the glacier bulldozes surficial outwash deposits into ice-proximal push moraines. Compression at deeper levels causes dislocation along the boundary between the overlying permeable outwash sands and silts, and underlying less-permeable glaciomarine deposits. Water lubricates this surface, reducing friction. The overlying outwash sediments are brittle and fracture along thrust zones. These sediments (bulges 1, 2 and 3) are transported relatively intact along a series of thrust faults. Measured glacier advance $(27 \mathrm{~m}$ ) is accommodated by thrusting of these sediments (at least $13.5 \mathrm{~m}$ ), by ice overriding ice-proximal sediments, by compaction of proglacial sediments and by continued excavation.

an old lodgement till. The sediment wedge was squeezed against a drumlin, resulting in folds and a series of imbricate thrust faults that propagated up from a décollement at the outwash-till contact. Continued ice advance and compression eventually caused deformation of the underlying older till. The resulting moraine complex, with a maximum elevation of $11 \mathrm{~m}$ above base surface, consisted of a series of narrow, multi-crested ridges spread over a width of $40 \mathrm{~m}$. In comparison, although similar in height, the complex of proglacial bulges at Taku Glacier was four times as wide and occurred along a much longer section of the terminus. The distance between ridge crests was also significantly greater. Many of the thrust zones at Taku appeared to be incipient, with new dislocations being developed and old ones reactivated as the glacier began to readvance. Folding of sediments appeared to be confined to the fronts of the bulges. Two other differences are that there are no down-glacier obstructions at Taku, which might enhance imbricate stacking of overthrust sediments, nor any underlying lodgement till.

It has been suggested that permafrost is essential for development of large-scale push moraines and that they may provide evidence of permafrost conditions in the Pleistocene record (Boulton and others, 1999). However, the scale of push moraines at Taku Glacier approaches those developed by glacier advance in presently permafrosted terrains. Thus, permafrost may not always be a prerequisite for large-scale push moraines. It has often been assumed that large, complex push moraines result mainly from glacier surges (cf. Bennett, 2001). The evidence from non-surging Taku Glacier suggests this is not always the case.

\section{Formation of push-moraine complex, a preliminary model}

Growth and advance of the ice-proximal push moraines at Taku appears to be driven by two mechanisms:

(1) bulldozing of surficial material by advancing ice; and

(2) prograding of till deposited on the moraine.

Such ice-proximal push moraines are similar to those described at other glaciers and are relatively common
(Humlum, 1985; Kruger, 1985; Eybergen, 1987; Bennet, 2001). We therefore focus on the long-wavelength proglacial bulges because these features have rarely been seen in active development in front of temperate glaciers. We re-emphasize that, thus far, our study has been limited in scope and any interpretive model is accordingly qualitative. We begin by summarizing some characteristics of Taku Glacier and its advance, which have bearing on proglacial sediment deformation.

One of the most distinguishing features of Taku is its advance over a thick accumulation of soft sediments because it was until recently a tidewater glacier (Motyka and Post, 1995; Nolan and others, 1995). In contrast, most other currently advancing or surging glaciers flow over bedrock or over a veneer of till $(<10 \mathrm{~m})$ overlying bedrock. Radio-echo soundings in 1990 showed that Taku Glacier had deeply entrenched itself into these subglacial sediments, by as much as $140 \mathrm{~m}, 1.5 \mathrm{~km}$ up from the 1990 terminus (Fig. 2; Nolan and others, 1995). From 1952-90 the ice at this location thickened from $0-340 \mathrm{~m}\left(9 \mathrm{~m} \mathrm{a}^{-1}\right)$ (Fig. 2). Some of the entrenchment likely resulted from compaction of underlying soft sediment, but, given the amount of change, sediment excavation by glacier erosion has certainly been the primary mechanism. Over-deepening of the glacier bed was documented to within $300 \mathrm{~m}$ of the terminus in 1990 (Fig. 2; Nolan and others, 1995). Surface elevation at the terminus continued to increase, $10 \mathrm{~m}$ between 1993-99 (Fig. 3b). It seems reasonable to assume that excavation and entrenchment was also continuing and prograding to the terminus. The rate of entrenchment averaged $3.7 \mathrm{ma}^{-1}$ at the 1952 location over a 38 year period. If entrenchment near the terminus was occurring at even half this rate, substantial overdeepening, $\sim 20 \mathrm{~m}$, would still have taken place since 1990.

Taku Glacier has produced subaerial push moraines since at least 1950, when a shoal composed of glaciofluvial outwash sediments emerged from tidewater in front of the advancing terminus (Motyka and others, 1992; Motyka and Post, 1995). Super-elevated terrain formed and has remained at the same location relative to the terminus face, despite continuous glacier advance. Some compaction of the poorly consolidated sediments has probably occurred in response to the compressive stresses associated with glacier advance, but 
the primary response to these compressive stresses was thrust faulting (Fig. 9).

Based on our measurements of bulge advance from 6 June to 1 September 2001, the combined horizontal movement along the thrust faults underlying bulge 1 and 2 was $13.5 \mathrm{~m}$, with $8.1 \mathrm{~m}$ occurring under bulge 1 and $5.4 \mathrm{~m}$ under bulge 2. This movement is about half the total glacier advance of $27 \mathrm{~m}$ during the same time period (Fig. 9). The displacement of the proximal bulge (3) was not measured. Some of the difference could have been taken up along this third and most proximal bulge, with the rest by sediment compression, glacier advance over proglacial terrain and excavation of sediments.

Figure 9 presents a schematic model of these processes. The glacier surface geometry is from 2000 airborne profiling (K. A. Echelmeyer, unpublished data); the proglacial bulges are from our September 2001 surveys. The recent subglacial boundary is conjecture, but we assume some entrenchment has taken place. Mollusk shells found in the till indicate that the glacier is excavating marine deposits. The boundary between glaciofluvial outwash and underlying glaciomarine deposits is assumed to be at or slightly below sea level. Thus, advancing ice may be applying pressure to the top 25-30 $\mathrm{m}$ of the sediments forward of the terminus. The underlying glaciomarine mud is relatively impermeable, compared to the overlying porous outwash silts and sands, so pore-water tends to accumulate at this interface. The two units also differ markedly in their ductility, the overlying outwash sands and silts being significantly less cohesive. Given the hydrogeology and structural weakness of the boundary between the two units, friction would likely be very low and therefore décollement is likely to occur in such a zone. Figure 9 shows thrust faults propagating upward from such a zone into the overlying outwash sediments. Little or no deformation occurs in these outwash sediments except near the front of the overthrusts. Thus thrusts rather than folds dominate the structural form of the observed push-moraine complex. Bennett (2001) proposed that very low or friction-free sliding along a basal décollement can lead to thrust-dominated moraines and that this type of push moraine may have larger proximal-distal widths. Our preliminary studies at Taku Glacier, where the push moraine is $200 \mathrm{~m}$ wide, support these propositions.

\section{GONGLUSIONS}

Taku Glacier has produced a variety of proglacial glaciotectonic features during its history of advance. It was previously a calving tidewater glacier that subsequently built its terminal-moraine shoal into a proglacial outwash plain that is a few to several meters above sea level. In 2001, a portion of the glacier terminus began advancing at $30 \mathrm{~cm} \mathrm{~d}^{-1}$. Ice advanced onto an elevated shoal, overriding vegetation and pushed into the proglacial sediments, causing two to three large, long-wavelength proglacial bulges to develop. The bulges grew to heights of 3-10 $\mathrm{m}$, decreasing from the ice front outward. The leading edge of the most distal bulge was $200 \mathrm{~m}$ from the active terminus. The bulges propagated forward at $9-15 \mathrm{~cm} \mathrm{~d}^{-1}$ during summer 2001. Proglacial sediment deformation disrupted surface vegetation, creating crenulations, folds and tears. Significant folding occurred within the snouts of these bulges; sediment bedding more distal to snouts was undistorted and subhorizontal. Thrusting of sediments took place along shear zones that lead up to and inter- sect the ground surface at the toes of these bulges. Total movement along thrust planes under bulge 1 and 2 during summer 2001 is estimated at $13.5 \mathrm{~m}$ compared to a glacier advance of $27 \mathrm{~m}$. Movement of proglacial sediments along thrust faults thus accounts for at least half of the glacier advance over the same time period. The residual is likely accounted for by movement at other, unmeasured faults, ice flowing up and over terrain, subglacial excavation of soft sediments and compaction of sediments.

Over the same period, there were areas along the terminus where proglacial sediments were relatively undisturbed, indicating there must be some critical combination of factors necessary for proglacial sediment deformation to occur. Speed of advance and the relative height of proglacial sediments are probably important.

Thickening of ice in the terminus region of Taku Glacier indicates the glacier will continue to advance, at least for the near future. This continuing advance will provide an opportunity to examine the dynamics of glacier termini, such as how stresses and motion transmit through the terminal region and how the dynamics of glacier advance differ from those of retreat.

\section{ACKNOWLEDGEMENTS}

Support for this work was provided in part by U.S. National Science Foundation grants OPP-9876421 and OPP-0221307. We would like to acknowledge A. Clough for alerting us to the recent advance and thank D. H. Elsberg, M. Truffer, V. B. Valentine and S. Zirnheld for help in the field and manuscript preparation. The manuscript benefited greatly from comments made by N.F. Glasser, D. E. Lawson and an anonymous reviewer.

\section{REFERENCES}

Aber, J. S., D. G. Croot and M. M. Fenton. 1989. Glaciotectonic landforms and structures. Dordrecht, etc., Kluwer Academic Publishers. (Glaciology and Quaternary Geology 5.)

Arendt, A. A., K. A. Echelmeyer, W. D. Harrison, C. S. Lingle and V. B. Valentine. 2002. Rapid wastage of Alaska glaciers and their contribution to rising sea level. Science, 297(5580), 382-386.

Bennett, M. R. 2001. The morphology, structural evolution and significance of push moraines. Earth Sci. Rev., 53(3-4), 197-236.

Boulton, G. S., J. J. M. van der Meer, D. J. Beets, J. K. Hart and G. H. J. Ruegg. 1999. The sedimentary and structural evolution of a recent push moraine complex: Holmstrømbreen, Spitsbergen. Quat. Sci. Rev., 18(3), 339-371.

Croot, D. G. 1987. Glacio-tectonic structures: a mesoscale model of thinskinned thrust sheets? 7. Struct. Geol., 9 (7), 797-808.

Croot, D. G., ed.. 1988a. Glaciotectonics: forms and processes. Rotterdam, A.A. Balkema.

Croot, D. G. 1988b. Glaciotectonics and surging glaciers: a correlation based on Vestspitsbergen, Svalbard, Norway. In Croot, D.G., ed. Glaciotectonics: forms and processes. Rotterdam, A.A. Balkema, 49-61.

Echelmeyer, K. A. and 8 others. 1996. Airborne surface profiling of glaciers: a case-study in Alaska. 7. Glaciol., 42(142), 538-547.

Etzelmüller, B., J. O. Hagen, G. Vatne, R. S. Ødegård and J. L. Sollid. 1996. Glacier debris accumulation and sediment deformation influenced by permafrost: examples from Svalbard. Ann. Glaciol., 22, 53-62.

Eybergen, F.A. 1987. Glacier snout dynamics and contemporary push moraine formation at the Turtmannglacier, Wallis, Switzerland. In Van der Meer, J. J. M., ed. Tills and glaciotectonics. Rotterdam and Boston, A. A. Balkema, 217-231.

Hagen, J. O. 1987. Glacier surge at Usherbreen, Svalbard. Polar Res., 5(2), n.s., 239-252.

Hart, J. K. 1995. An investigation of the deforming layer/debris-rich basal ice continuum, illustrated from three Alaskan glaciers. 7. Glaciol., 41 (139), 619-633.

Hart, J. K. and R. Watts. 1997. A comparison of the styles of deformation associated with two recent push moraines, south Van Keulenfjorden, 
Svalbard. Earth Surf. Processes Landforms, 22(12), 1089-1107.

Humlum, O. 1985. Genesis of an imbricate push moraine, Höfoabrekkujökull, Iceland. F. Geol., 93(2), 185-195.

Kälin, M. 1971. The active push moraine of the Thompson Glacier, Axel Heiberg Island, Canadian Arctic Archipelago, Canada. Montréal, Que., McGill University. (Axel Heiberg Island Research Reports Glaciology 4.)

Krüger, J. 1985. Formation of a push moraine at the margin of Höfðabrekkujökull, south Iceland. Geogr. Ann., 67A(3-4), 199-212.

Motyka, R. J. andJ. E. Begét. 1996. Taku Glacier, southeast Alaska, U.S.A.: Late Holocene history of a tidewater glacier. Arct. Alp. Res., 28(1), 42-51.

Motyka, R. J. and A. Post. 1995. Taku Glacier: influence of sedimentation, accumulation to total area ratio, and channel geometry on the advance of a fjord-type glacier. In Engstrom, D. R., ed. Third Glacier Bay Science Symposium, 14-18 September 1993. Proceedings. Anchorage, AK, National Park Service, $38-45$.

Motyka, R. J., R. S. Noll and D. C. Trabant. 1992. Taku Glacier. Alaska Div. Geol. Geophys. Surv. Inform. Circ. 34, 1 sheet.
Motyka, R. J., S. O'Neel, C. L. Connor and K. A. Echelmeyer. 2002. 20th century thinning of Mendenhall Glacier, Alaska, and its relationship to climate, lake calving, and glacier run-off. Global Planet. Change, 35(1-2), 93-112.

Nolan, M., R. J. Motyka, K. Echelmeyer and D. C. Trabant. 1995. Ice-thickness measurements of Taku Glacier, Alaska, U.S.A., and their relevance to its recent behavior. F. Glaciol., 41(139), 541-553. (Erratum: 42(141), 1996, p. 400.)

Pelto, M. S. and M. M. Miller. 1990. Mass balance of the Taku Glacier, Alaska from 1946 to 1986. Northwest Sci., 64(3), 121-130.

Post, A. 1975. Preliminary hydrography and historic terminal changes of Columbia Glacier, Alaska. U.S. Geol. Surv. Hydrol. Invest. Atlas HA-559, 3 maps. (Scale 1:10,000.)

Post, A. and R. J. Motyka. 1995. Taku and LeConte Glaciers, Alaska: calvingspeed control of Late-Holocene asynchronous advances and retreats. Phys. Geogr., 16(1), 59-82.

Van der Meer, J. J. M. 1987. Tills and glaciotectonics. Rotterdam, A. A. Balkema.

MS received 6 March 2002 and accepted in revised form 13 December 2002 